\title{
THE INTERPLAY BETWEEN FIRMS' INTERNAL AND EXTERNAL CAPABILITIES IN EXPLORATION AND EXPLOITATION ${ }^{1}$
}

\author{
César Camisón \\ Universitat de València (Spain) \\ Montserrat Boronat-Navarro ${ }^{2}$ \\ Universitat Jaume I (Spain) \\ Beatriz Forés \\ Universitat Jaume I (Spain)
}

\footnotetext{
${ }^{1}$ This work was supported by the National Plan for R\&D of the Spanish Ministry of Economy and Competitiveness (ECO2012-36780 and EC02016-76796-P); and the Fundació Caixa Castelló-Bancaixa in the context of the Universitat Jaume I Annual Research Plan (P1-1A2011-15 and UJI-A2017-04).

${ }^{2}$ Corresponding author. Email: mboronat@ uji.es. Postal address: Universitat Jaume I, Department of Business Administration and Marketing, Av. Sos Baynat s/n, 12071 Castellón (Spain). Tel.: +34 964 728541; fax: +34 964728629 .
} 


\title{
THE INTERPLAY BETWEEN FIRMS' INTERNAL AND EXTERNAL CAPABILITIES IN EXPLORATION AND EXPLOITATION
}

\author{
Abstract \\ Purpose \\ The purpose of this study is to enrich the explanation of the interplay between internal and external - or \\ district shared - exploration and exploitation capabilities as antecedents of a firm's radical and \\ incremental innovation. Previous studies do not differentiate between exploration and exploitation in \\ district shared capabilities and how they interact with internal capabilities. \\ Design/Methodology/Approach
}

The paper uses hierarchical regression analysis to test the quadratic and moderating effects in a sample of 1019 Spanish firms.

Findings

Results show an increasingly positive effect on radical innovation of exploration capabilities, enhanced by shared capabilities in exploration. In the case of incremental innovation, the study finds evidence of an increasingly positive influence of exploitation capabilities and a concave relationship of exploration capabilities. Moreover, shared exploitation capabilities weaken the effect of internal exploitation capabilities and also have a direct effect on incremental innovation. Therefore, the two capabilities are interchangeable in the effect they have on incremental innovation.

Practical implications

Depending on the firm's innovation strategy, intra-district firms should develop specific capabilities and/or concentrate on adopting the shared capabilities in the destination.

Originality/value

The study furthers understanding of the relationship between exploration and radical innovation, and between exploitation and incremental innovation, which is more complex than previously depicted. The study also differentiates between exploration and exploitation in shared capabilities, enriching understanding of the competitiveness of district firms. 


\section{Introduction}

Firms invest in building learning capabilities that allow them to access, deploy and leverage resources and knowledge in order to develop innovations (Barney, 1991; Grant, 1996; Nonaka, 1994; Wernerfelt, 1984). For knowledge and learning to evolve, investments must be made in exploration and exploitation capabilities (He and Wong, 2004; Levinthal and March, 1993; March 1991). Specifically, this study analyzes the firm's exploration and exploitation capabilities as the main antecedents of radical and incremental innovation types.

Following March's seminal study (March, 1991), several authors have analyzed and defined these two types of capability. Exploration aims to develop new knowledge, while exploitation concerns the use and development of existing knowledge (Levinthal and March, 1993). Authors such as Levinthal and March (1993) and Atuahene-Gima (2005) reflect this distinction by considering both capabilities as fundamental for firm innovation. Consistent with these definitions, and following March's (1991) conceptualization, in this study we consider that exploration capabilities comprise the firm's capabilities to create, search for and absorb new knowledge, whereas exploitation capabilities are related to the refinement and combination of the existing knowledge in new ways (Atuahene-Gima, 2005; Levinthal and March, 1993). Whereas exploration pursues variation and experimentation with new ways of doing things, exploitation focuses on efficiency and reliability.

The extant literature has analyzed different aspects of exploration and exploitation in depth, but has not widely analyzed capabilities and their results together in terms of radical and incremental innovations. Some studies measure innovation directly as explorative or exploitative (e.g., Li et al., 2008).

Furthermore, authors who introduce capabilities and innovative results in the same model indicate that exploration capabilities may benefit radical innovation only, while hindering incremental innovation (e.g. Atuahene-Gima, 2005) and the opposite effect in the case of exploitation capabilities. This study contributes to these topics by offering an in-depth analysis of the implicit assumption that exploration only has a positive linear effect on radical innovation, and exploitation, on incremental innovation. Furthermore, the term tourism district, coined since the work of Molteni and Sainaghi (1997), has been highlighted as a fundamental aspect in relevant studies on tourism firms' innovation (Bell, 2005; Lazzaretti and Petrillo, 2006; Novelli et al., 2006; Sørensen, 2007). External or shared capabilities reflect the knowledge, processes and skills generated in the district as a whole, embedded in its routines and in the relationships among the agents that participate in it (Foss, 1996). The simultaneous pursuit of internal 
and external sources of knowledge makes the tourism sector an especially appropriate context in which to investigate the relationship between firm-specific and shared capabilities in predicting a firm's innovative output. This study distinguishes between radical and incremental innovation. The difference between both lies in the degree of changes they generate: radical innovation produces fundamental changes in the firm's structure, procedures and activities, whereas incremental innovation produces small changes (Damanpour, 1991; Dewar and Dutton, 1986; Ettlie et al., 1984). Understanding the antecedents of radical innovation compared to incremental innovation in tourism firms is highly relevant on both a theoretical and a practical level, since managers should consider differences between radical and incremental antecedents when deciding where to assign resources.

The objective of this paper is therefore to analyze the interaction of firms' internal capabilities and external or shared capabilities and their effect on both radical and incremental innovations in the tourism sector by distinguishing between exploration and exploitation in the two types of capabilities. The study contributes to the existing empirical literature by showing how the pattern of the direct and moderated effects is different in the two types of innovation, and is more complicated than previously depicted.

\section{Literature review and hypotheses development}

\subsection{Tourist districts and shared capabilities}

The tourist district is defined as an agglomeration in a geographical area of a range of diverse and complementary entities, such as associations, consortia or universities, and firms from different sectors with stable relationships between them, that share a culture and values, and that offer complementary tourism products and services to configure a broad tourist experience (Sainaghi, 2006).

Local systems like districts are recognized as repositories of knowledge and skills (Novelli et al., 2006; Sainaghi, 2006; Saxena 2005). The concept of shared capabilities captures the district's knowledge and skills, which are embedded in its processes and actors. Camisón (2004) states that shared capabilities or competences (the two terms are used synonymously in this paper) consist of social capital that encourages flows of knowledge between district agents and complementary assets which facilitate services for intradistrict firms. His definition emphasizes the importance of the values, knowledge and ideas of the community of people who make up the district, and the institutions and rules generated by the interorganizational relationships and networks established in it. His seminal definition of shared capabilities stems from the definition of firm capabilities derived from the dynamic view of the resourcebased view, although with the concept extended to the sphere of districts (Lawson, 1999). Their 
intangibility and tacit nature make them important as a source of competitive advantage, but mere location inside the district is not enough to benefit from shared capabilities (Wu et al., 2010). Firms must be engaged in the development and implementation of activities, policies and learning processes to take advantage of the external or shared capabilities in the district (Lei and Huang, 2014; Li et al., 2015).

The strategic literature has adopted several related terms to refer to those shared district assets. For example, Foss (1996) defines them as 'higher-order capabilities'; Maskell and Malmberg (1999) present them as 'cluster capabilities'; Li et al. (2015) adopt the widely-used term 'shared resources'; whereas other authors refer to this concept as collective capabilities (Fløysand and Jakobsen, 2002). For their part, Lawson and Lorenz (1999) and Pinch et al. (2003) adopt the terms 'shared knowledge' and 'clusterknowledge', respectively. By contrast, emphasizing the underlying learning processes in the generation of these capabilities, instead of knowledge components themselves, authors such as Capello (1999) introduce the term 'collective learning', also used by other authors (e.g. Capello and Faggian, 2005; Cotic-Svetina and Jaklic; 2008, Cotic-Svetina et al., 2008; Chuang et al., 2016; Lawson, 2000; Lawson and Lorenz, 1999). Chuang et al (2016: 1445) incorporate these contributions in their definition, considering collective learning as an interactive process where knowledge is accumulated from different local resources or channels (Cotic-Svetina et al., 2008) through interactive mechanisms based on shared rules, norms, organizations, and procedures (Capello, 1999).

What is clear from the analysis of the literature is the consensus that these agglomeration economies are shared by intra-district firms, strengthing the notion that the knowledge and resources found in these agglomerations are public goods for all intra-cluster members, derived from the network relationships the local firms enjoy (Dyer and Singh, 1998; Chang et al., 2010).

In this paper, following Camison's (2004) conceptualization, we adopt the term capabilities (Grant, 1991; Amit and Schoemaker, 1993) rather than the wide conceptualization of resources (Barney, 1991; Peteraf, 1993) to stress the importance of those intangible and complex abilities in transforming external strategic resources into sources of competitive advantage for those intra-district firms.

The adoption of the strategic perspective, introduced above, to define and analyze these externalities inside the district avoids inconsistencies in the parallel methodological approaches followed in the literature, most of which focus exclusively on economic variables (without considering the importance of other cultural, cognitive and social variables). 
Some authors also distinguish different types of district capabilities in their analyses. Following the knowledge-based view, Pinch et al., (2003) bring Henderson and Clark's (1990) conceptualization of component and architectural knowledge of products to the level of analysis of the firm and district knowledge. According to Pinch et al. (2003) component knowledge is closely related to the traditional norms and rules operating in a sector, and it is more easily transferred between firms than architectural knowledge, which belongs to the system as a whole entity and emerges from the interactions between district actors (Pinch et al., 2003). Asheim and Coenen (2005) also introduce the distinction between regional knowledge exploitation and regional knowledge generation subsystems.

In developing those ideas in this study the distinction is made between shared capabilities in exploration and shared capabilities in exploitation. The distinction between these shared capabilities, which goes further than Camisón's (2004) conceptualization of the construct, is dependent on the identification of the underlying learning and interactive process, mechanisms, and agents that generate them (Chuang et al., 2016), beyond the knowledge components themselves.

As our focus is the shared capabilities of the district and the intra-district firms' capabilities, we adopt the terminology most widely used to reflect the nature and aim of capabilities, following seminal contributions by March (1991), that distinguish between a firm's exploitation and exploration capabilities. This distinction thus allows us to examine and contrast how the firm's capabilities interact with those of the district.

Shared capabilities in exploration include the presence of knowledge flows and information creation and dissemination and are based on architectural knowledge involving a variety of actors dispersed in the system. These actors may be local institutions that facilitate access to collective knowledge, a permeable social structure that enables the informal flow of knowledge and experience, cooperation relationships with the members of the value chain and experts and consultants, available qualified and specialized human resources, and the existence of intra-district benchmarking. Therefore, all of these sources of knowledge should provide variation, experimentation and discoveries through the cross-fertilization of ideas between districts.

In contrast, shared capabilities in exploitation consist of district-specific component knowledge closely related to the traditional technological trajectory in the district, customer preferences, and to the norms and rules that operate in a particular sector. They may be local institutions that strengthen the district image, the shared vision among firms, the strategic plan for the district, and firms working together to 
offer a comprehensive tourism product. Shared capabilities in exploitation are also grounded in the privileged location of the intra-district firms, and in the efficiency that comes from sharing resources, tasks and individuals among activities.

The distinction we introduce between the two types of shared capabilities is based on Camison's (2004) aggregated conceptualization of the construct (as it is the conceptualization in the literature that most precisely identifies existing dimensions and factors), and includes the main constituents currently identified in the strategic literature on districts (e.g. Li and Geng, 2012; Wu et al., 2010).

\subsection{Capabilities and radical innovation}

Radical innovation calls for changes in many aspects of the firm's asset and knowledge base (Henderson and Clark, 1990). Exploration capabilities focus mainly on creating variety, on risk and on experimentation, which in turn should result in radical changes (Atuahene-Gima, 2005). Exploration capabilities expand a firm's knowledge base, encourage departure from current skills (Benner and Tushman, 2003; Levinthal and March, 1993; March, 1991), and imply operations beyond the scope of what the firm currently knows (March, 1991). Furthermore, exploration capabilities are also needed to absorb new external knowledge (Cohen and Levinthal, 1990), especially non-articulated and tacit forms of knowledge, and knowledge that is not closely related to the firm's previous knowledge base (Camisón and Forés, 2010) to transform it into radical innovation. Hence, exploration capabilities facilitate radical innovation at an increasing speed, which leads to the first research hypothesis.

\section{H1. Exploration capabilities have an increasingly positive relationship with radical innovation, such that they have (a) a positive linear effect and (b) a positive quadratic effect on radical innovation.}

Firms with higher local linkages with suppliers, subcontractors, customers and support institutions in the tourist district have more opportunities to be exposed to knowledge, and therefore more opportunities for radical innovation. Accessing new knowledge from external sources increases variation and experimentation in technologies inside firms (Clausen et al., 2013).

An atmosphere of cooperation stimulates experimentation with knowledge combinations, inspiring members to be more creative in their innovation activities (Cuevas-Rodríguez et al., 2013). Trust between agents also improves their capability to evaluate and acquire information and valuable knowledge (Inkpen and Tsang, 2005) and transform it into radical innovations. 
Public sector organizations, trade associations, universities and research institutes also play a fundamental role in providing information about both technologies and markets. Local institutions are also connected with global networks outside the district (Malmberg and Maskell, 2002) that open up different intradistrict potentialities, feed local interpretation and usage of knowledge hitherto residing elsewhere, and help counteract technological ‘lock-in’ within regional districts of firms (Giuliani and Bell, 2005).

However, despite the benefits of a set of shared capabilities in exploration, their existence in the destination firm's environment will not be sufficient to ensure that it internalizes them satisfactorily to allow radical innovation. Shared capabilities in exploration refer to new capabilities and knowledge not linked to previous routines and cognitive structures in the firm. Consequently, if firms want to capitalize on new external knowledge they should develop their internal exploration capabilities (Storey and Kahn, 2010). A firm's investment in developing its internal exploration capabilities is not only important to guarantee the acquisition and application of district knowledge but also, as authors such as Giuliani and Bell (2005) have pointed out, to be perceived by other district firms as a valuable firm with an advanced knowledge base or even as 'technological leaders' in the local area. Therefore, shared capabilities in exploration strengthen the positive link between a firm's exploration capabilities and radical innovation.

\section{H2: Shared capabilities in exploration strengthen the positive effect of exploration capabilities on radical innovation.}

\subsection{Capabilities and incremental innovation}

Diversity in knowledge, provided by an extensive search for knowledge and technological trends in which exploration capabilities are based, also aids the expansion of existing knowledge through the crossfertilization of ideas (Quintana-García and Benavides-Velasco, 2008). Dewar and Dutton (1986) demonstrate how diversity in the knowledge base, measured by the number of people in different technical specialties representing diverse knowledge resources, aids radical innovation and, although to a lesser extent, also enhances incremental innovation. Martínez-Ros and Orfila-Sintes (2009) state that resources and capabilities developed for certain degrees of innovation will also have value for the other degrees: exploration capabilities that are expected to produce new knowledge deriving in radical innovations are also valuable in incremental innovations.

However, there will be decreasing returns to incremental innovation as exploration capabilities increase. As firms move to create disruptive knowledge and changes, their internal knowledge base, capabilities and technologies require a fundamental transformation. A loss of innovative efficiency occurs with this 
accumulation of technological discontinuities. As pointed out by Berchicci (2013), exploration capabilities slow down learning-by-doing and impede the building of path-dependent knowledge stock inside the firm. The lower impact of exploration capabilities on incremental innovation may also arise because of diseconomies of scope (Hess and Rothaermel, 2011). Relying heavily on new knowledge generation implies high levels of external sourcing search, and coordinating and monitoring costs, and could hamper the building of path-dependent knowledge stocks within the firm (Berchicci, 2013). Therefore, the positive effect of exploration capabilities on incremental innovation is expected to decrease when a firm opens up substantial new knowledge areas. Hence, the third hypothesis is:

\section{H3. Exploration capabilities have a curvilinear relationship with incremental innovation, such that they have (a) a positive linear effect and (b) a negative quadratic effect on incremental innovation.}

Exploitation capabilities have been shown to improve efficiency and focus on providing new solutions that are close to the firm's current experience (March, 1991; Lavie and Rosenkoft, 2006). Exploitation capabilities give firms a better understanding of the value and applications of knowledge related to their existing knowledge base, and therefore provide the foundation on which to develop their current skills, products and processes (Benner and Tushman, 2003). Thus, the firm's knowledge base is strengthened and new connections are identified (Clausen et al., 2013). Clausen et al. (2013) state that the most efficient way to produce incremental innovations is by improving current practices. This study extends the literature by arguing that the search for familiar and proximate knowledge through exploitation capabilities may facilitate incremental innovation at an accelerating rate, such that a unit increase of exploitation capabilities relates to increasingly higher levels of incremental innovation. When firms invest resources in promoting their exploitation capabilities, employees become embedded in this culture of continuous improvement and learning. The following hypothesis presents this idea.

\section{H4. Exploitation capabilities have an increasingly positive relationship with incremental innovation, such that they have (a) a positive linear effect and (b) a positive quadratic effect on incremental innovation.}

Intra-district firms have free access to the district's capabilities in exploitation, since the cognitive models, goals, culture, heuristics and structures that underlie the generation of knowledge are shared by and known to all the firms integrated in it (Tsai and Goshal, 1998). Because the district's capabilities in exploitation can be easily absorbed and integrated, they can be transferred directly to improve the firm's processes, operations and existing knowledge base, impacting on their incremental innovation without 
previously having to be filtered by the firm; in other words, without being combined with their internal capabilities. This direct effect appears to be rooted in the canonical literature (e.g., Boari and Lipparini, 1999), which perceives that all the knowledge flows circulating within a district can be automatically exploited by all the firms embedded in it.

This means that the incentive of an intra-district firm, exposed to the shared capabilities in exploitation, to invest in developing its internal capabilities in exploitation, whose impact is limited to incremental innovation, will gradually decline. Hence, in the case of incremental innovation the capabilities in external and internal exploitation will act as substitutes: either the firm will produce incremental innovation because it is in a district, by taking advantage of the shared capabilities in exploitation; or it will achieve incremental innovation by developing its own internal capabilities in exploitation.

Furthermore, the isomorphic pressure of the organizational model and the standardized technological patterns that underlie the generation of shared capabilities in exploitation mean that the firm's capabilities to combine its own internal knowledge will be limited. In the development of shared capabilities in exploitation each agent knows its role, its goals, and the final objective of its own efforts. Engagement in shared capabilities in exploitation exercises certain pressure and control that demand compliance with norms of conformity that may deter firms from acting in ways that promote innovative combinations of their existing knowledge when these knowledge exploitative capabilities involve a significant deviation from the norms and patterns established in the district (Cuevas-Rodríguez et al., 2013).

The high degree of cohesiveness of the firms that make up the overall tourism product of the district, which implies accepting and sharing certain goals, the culture, and a common strategic model that are the base for shared capabilities in exploitation, could be detrimental to the firm's exploitation capabilities. Individuals may become too relaxed, which may lead to them to accept their partners' ideas too readily, with the resulting fall in creative tension and a reduction of the partnership's effectiveness in differentiating its capabilities to introduce novel recombinations of internal knowledge and ideas (Guler and Nerkar, 2012). These arguments suggest that there are decreasing returns to incremental innovation as exploitation capabilities of firms exposed to shared capabilities in exploitation increase. Therefore:

\section{H5: Shared capabilities in exploitation weaken the positive effect of exploitation capabilities on incremental innovation.}

\section{Methodology}




\subsection{Sample and data collection}

The empirical study was carried out using a database of Spanish tourism firms. The researchers requested from the National Statistics Institute's Central Directory of Spanish Companies in order to determine the reference universe and its geographical distribution by activity, size, autonomous community and province. Data are collected through a questionnaire answered by the firm's owner, senior/general manager or CEO. The procedures follow usual recommendations in designing surevey research (Dillman, 1978; Podsakoff and Organ, 1986). Before applying the final questionnaire it was pretested on a group of five academics and eight managers from firms of different sizes and activities in the tourism sector and subsequently refined. Control items are also included in which the meaning of the statement is reversed compared to the other scale items. The instrument includes also questions on the same topic in different sections to control for response reliability. Questions from different dimensions of constructs are mixed to mitigate the problem of dependency in the respondents' answers and dependent variables are placed after independent variables (Podsakoff and Organ, 1986).

The fieldwork took place between December 2009 and March 2010. The final sample contains 1,019 firms, which from the sector universe reflects a statistical margin of error of $\pm 3.1 \%$ (confidence interval of $95.5 \%$ ). The composition of the final sample is similar to the structure of the sector, both in terms of activity and size. Early and late responses are compared to control for non-response bias (Armstrong and Overton, 1977); results of the t-tests reveal no significant differences in any explanatory or dependent variables.

\subsection{Measurement of variables}

Dependent variable. Two models are estimated to test for differences in antecedents of radical and incremental innovation. In both models the dependent variable - radical/incremental innovation - is measured with objective, zero-one scale items that are summed to obtain an innovation score. The items capture the new technologies or instruments for managing the business process (see Appendix) and are developed following Sundbo, Orfila-Sintes, and Sørensen (2007), but distinguishing different technologies relevant to the tourist industry as identified by other studies in the tourism literature (Buhalis and Law, 2008). Three criteria are used to classify the items as radical or incremental instruments, following the traditional studies in the innovation literature. The first one is the cost of the change. If adopting a new technology involves changes in products or processes and it is different from the existing practice, it implies a higher cost (Ettlie et al., 1984). The second criterion is the degree of new knowledge 
it requires: innovations that require unfamiliar knowledge with higher uncertainty are considered as radical (Dewar and Dutton, 1986). Finally, the third criterion is the repercussion in the firm's structure and activities: innovations that entail fundamental changes in the organization of work and service provision are considered to be radical (Damanpour, 1991). Incremental innovations are those that imply small changes in products or processes, structure and activities, and that require familiar knowledge.

Independent variables. The scales used in this study (see Appendix) are those proposed by AtuaheneGima (2005) and follow March's conceptualization of exploration and exploitation (March, 1991). These scales have also been widely tested in other empirical studies (e.g. Arnold et al., 2011; Wang and Rafiq, 2014).

Moderating variables. Based on the previous definitions, items are adapted from the scale of shared capabilities proposed by Camisón (2004), which forms the basis for the theoretical definition of the construct. This author performed one of the most thorough analyses in the literature, identifying the specific dimensions and factors that comprise shared capabilities, and put into practice by means of a robustly validated and widely-used multi-item scale.

Specifically, shared capabilities in exploration are measured with five items adapted from the dimensions of external acquisition of knowledge and of collective learning in Camisón's study (Camisón, 2004) (see Appendix). Shared capabilities in exploitation comprise five items adapted from the dimensions of shared vision, collective reputation and value system, also from the same study (see Appendix).

Control variables. Age is included as the logarithm of number of years since the first establishment was opened. Size is measured as the natural logarithm of total number of employees. Environmental dynamism is measured with five items based on Dess and Beard's study (Dess and Beard, 1984; see Appendix); the average rate of the items is then taken (Cronbach's alpha coefficient $=0.715)$. Finally, since the sample covers different activities, four dummy variables are introduced for accommodation firms, restaurants and catering firms, travel agencies and tour operators, and transport organizations, taking other complementary firms as the baseline.

\subsection{Reliability and validity}

Exploratory analysis is conducted and all of the expected constructs are formed (see Table 1). Construct validity, or the extent to which the items on a scale measure the theoretical construct, is assessed. 
Moreover, the results of the principal component analysis support the validity of the scales as indicated by the amount of variance explained (61.401\%), which exceeds $50 \%$.

$$
\text { ---Insert Table } 1 \text { about here--- }
$$

The inter-item consistency is assessed by composite reliability, estimated with Cronbach's alpha. Table 1 shows Cronbach alpha values of all factors above the threshold of 0.7. Confirmatory factor analysis is also performed to further test composite reliability. Composite reliability for each construct is over 0.755 (Table 1) and therefore exceeds the threshold of 0.7 (Fornell and Larcker, 1981).

Discriminant validity is evaluated from the correlations matrix. The levels of correlation between the variables are below 0.6 (see Table 2), confirming the discriminant validity of the model. The model fit indexes when exploration and exploitation are taken as two variances $(\mathrm{NFI}=0.900 ; \mathrm{NFI}=0.882 ; \mathrm{CFI}=$ 0.908 ; RMSEA $=0.122)$ are better than the results when they are taken together $(\mathrm{NFI}=0.779$; $\mathrm{NFI}=$ 0.724; $\mathrm{CFI}=0.786$; RMSEA $=0.186$ ), confirming discriminant validity.

---Insert Table 2 about here---

Discriminant validity is also examined with chi-square difference tests for the main model's subjective constructs in pairs. In the comparisons, the first model allows the correlation between the two constructs to be estimated, and in the second the correlation is fixed to 1 . The statistical significance of the chisquared difference is tested at $p<0.001$. By combining the main constructs of the model in pairs, six tests are performed (Ahire et al., 1996), all of which meet the criterion for discriminant validity (Anderson and Gerbing, 1988).

Composite reliability (Table 1) also demonstrates convergent validity since it is an indicator of shared variance among the items that reflect observed variables of a specific construct (Fornell and Larcker 1981). Finally, convergent validity is also evaluated through confirmatory factor analysis. Each measure loads on the expected construct and the model fit is acceptable (CFI $=0.951, \mathrm{IFI}=0.951, \mathrm{NFI}=0.910$, $\mathrm{NNFI}=0.943, \mathrm{RMSEA}=0.046$, Chi squared $=341.739, \mathrm{df} 164)$, thus demonstrating convergent validity Moreover, to evaluate convergent validity, predictive validity is tested from the correlation between innovation and economic performance. Economic performance is measured from the profit margin reported in the 2012 annual accounts compiled in the Iberian Balance Sheet Analysis System (SABI) database. The results indicate a significant positive correlation between performance and radical innovation $(r=0.105 ; p<0.05)$, and between performance and incremental innovation $(r=0.211 ; p<0.05)$. 
Harman's single-factor test (Podsakoff and Organ, 1986) is used to check for common method variance. Results yield four factors with eigenvalues greater than 1.0, with a total explained variance of $61.40 \%$. The first factor accounts for only $17.83 \%$ of the variance and, therefore, common method variance may not be a serious research bias. Confirmatory factor analysis also tests for common method bias (Menon et al., 1996) by linking all items to a single factor. The model that posits a single factor does not fit the data $(\mathrm{NFI}=0.591 ; \mathrm{NNFI}=0.572 ; \mathrm{CFI}=0.617$ RMSEA $=0.127)$, therefore showing that common method bias is not a problem.

\subsection{Analytical techniques}

Mean scores are calculated from the scale items to generate the composite scores for independent and moderator variables, and for the control variable environmental dynamism. The sum of the items is used in the case of the dependent objective variables radical and incremental innovation. The hierarchical regression analysis method is used to test the hypotheses. Three models are estimated for radical innovation and another three for incremental innovation. First the control variables are introduced, then the main effect variables and their quadratic term, and finally the moderating effects (Cohen and Cohen, 1983). Before entering the moderating effects, the main variables are mean centered to reduce multicollinearity (Aiken and West, 1991; Cohen et al., 2003). Before entering the moderating effects, the main variables are mean centered to reduce multicollinearity. Analysis of the variance inflation factors shows that multicollinearity is not a problem, with the highest factor at 2.433 belonging to an interaction with a quadratic term, below the cut-off level of 10 (Cohen et al., 2003).

\section{Results}

Table 3 shows the results. Models 1 to 3 explain radical innovation and Models 4 to 6 incremental innovation. Models 1 and 4 are the baseline specification, in the case of radical and incremental innovation, respectively, and include only the control variables. Models 2 and 5 include the main variables and their quadratic effects, and Models 3 and 6 are the full models that also include the interaction terms. Each subsequent model shows significant improvement over its baseline specification. The significance of the change in R2 is examined by an F-test. The addition of independent variables and their quadratic effect in Model 2 increases the variance explained by 8.7\% $(\delta \mathrm{F}=18.360, \mathrm{p}<0.001)$. Model 3 with the interaction terms results in an increase in $\mathrm{R}^{2}$ of $2.4 \%(\delta \mathrm{F}=3.478, \mathrm{p}<0.01)$. Regarding the incremental innovation, Model 5 increases the variance explained by $4.8 \%(\delta \mathrm{F}=23.990, \mathrm{p}<0.001)$ 
over the baseline model, and Model 6 shows an increment of $0.8 \%(\delta \mathrm{F}=2.550, \mathrm{p}<0.05)$. Therefore, the increases in $\mathrm{R}^{2}$ are significant, confirming the moderating and quadratic effects shown by coefficients.

---Insert Table 3 about here---

Exploration capabilities in Model 2 have a positive, significant effect on radical innovation $(\beta=0.237, p$ $<0.001)$, and a positive significant quadratic term $(\beta=0.080, \mathrm{p}<0.05)$, confirming predictions of $\mathrm{H} 1$, and finding a positive concave quadratic effect (Figure 1). Results partially support H2 in Model 3, since the coefficient of the interaction between exploration capabilities and shared exploration capabilities is positive and significant (Figure 2), which means that the positive effect of exploration capabilities is reinforced when they interact with shared capabilities in exploration $(\beta=0.111, p<0.05)$, although the same effect is not shown in the interaction between the quadratic term of exploration capabilities and shared capabilities in exploration $(\beta=0.025, \mathrm{p}>0.05)$.

\section{---Insert Figures 1 and 2 about here---}

Model 5 tests the third and fourth hypotheses. Exploration capabilities have a positive and significant linear effect on incremental innovation $(\beta=0.149, \mathrm{p}<0.001)$, and a significant negative quadratic effect ( $\beta=-0.096, p<0.001$ ), supporting H3. Specifically, a curvilinear and positive convex quadratic relationship is found (Figure 3). Exploitation capabilities have a significant and positive linear $(\beta=0.134$, $\mathrm{p}<0.001)$ and quadratic effect $(\beta=0.127, \mathrm{p}<0.001)$ on incremental innovation, supporting H4 (Figure 4). Hypothesis 5 is tested in Model 6. The interaction between exploitation capabilities and shared capabilities in exploitation is negative and significant $(\beta=-0.068, \mathrm{p}<0.01)$, and the interaction with the quadratic term of exploitation capabilities is also negative and significant $(\beta=-0.063, \mathrm{p}<0.05)$ (Figure 5). Therefore, H5 is also supported. Results for Model 6 also show a positive and significant effect between shared exploitation capabilities and incremental innovation.

---Insert Figures 3, 4 and 5 about here---

\section{Discussion and conclusions}

The findings contribute to the existing literature in different ways. First, the results provide a better understanding of the relationship between firms' exploration and exploitation capabilities in both radical and incremental innovation. 
On the one hand, firms with a high level of exploration capabilities can obtain radical innovations at an increasing rate. This finding supports previous studies suggesting that to sustain radical innovation firms need to develop the dynamic capabilities that enable them to reconfigure and create new knowledge and capabilities (Teece et al., 1997). However, the effect in the case of incremental innovation is different since as the firm's capabilities in exploration increase, their positive impact on incremental innovation declines. Incremental innovation mechanisms tend to be path dependent (Cohen and Levinthal, 1990), as they rely on accumulated skills and capabilities, and exploration capabilities involve breaking away from this investment and leveraging path. This result enhances understanding of previous studies that show no effect of exploration on incremental innovation (e.g., Atuahene-Gima, 2005) with the introduction of the quadratic effect.

On the other hand, a firm with exploitation capabilities enhances the use of its existing knowledge and expertise in incremental innovation at increasing speed, and strengthens its established positions.

However, the path in Figure 4 also shows that the firm needs to accumulate a certain level of exploitation capabilities in order for this 'take-off effect' to appear. In addition, although the study does not establish this specific hypothesis, the results show that the firm's capability to refine and extend existing knowledge has no effect on radical innovation.

All these findings thus enrich the extant literature by demonstrating the possible liabilities of capabilities in pursuing different innovation strategies. Second, the research extends knowledge of the impact of shared capabilities on the relationships between firm internal capabilities and innovation. This study, thus, provides further evidence on the complex relationship between exploration and exploitation and their interaction with other external variables (e.g., Chang et al., 2011; Yang and Li, 2011). Specifically, the investigation identifies and captures the complex nature of the shared capabilities in the district, distinguishing between shared capabilities in exploitation and shared capabilities in exploration. This provides further knowledge on the relationships between capabilities in exploration and exploitation, and radical and incremental innovation in the tourism sector, in which firms' competitiveness is closely linked to the interaction in a tourist destination or district.

Shared exploration capabilities may not directly affect radical innovation; rather, they must work together with firm's exploration capabilities to affect the development of new technologies, products and processes. Firms should develop their own knowledge base to be sufficiently equipped to recognize the value of external knowledge and technological trends, to assimilate them internally and to apply them for innovative outcomes (Cohen and Levinthal, 1990). Consistent with the study's proposals, shared 
capabilities in exploration were found to positively moderate the effect of exploration capabilities on radical innovation.

Shared capabilities in exploitation have a direct effect on incremental innovation and negatively moderate the effect of a firm's exploitation capabilities on incremental innovation. The ease with which the exploitation capabilities in the district can be identified and integrated means that they can be directly transferred to improve the firm's existing processes, operations and knowledge base, thereby affecting its incremental innovation, without having to be previously 'filtered' by the firm. The free access to these shared capabilities in exploitation in the immediate environment diminishes investment in intra-district firms' own exploitation capabilities by substituting firm exploitation capabilities. Relying exclusively on the acquisition and management of shared capabilities in exploitation may foster myopic learning, and inhibit experimentation and recombinations of the existing knowledge base.

The assumption that shared capabilities are freely available public knowledge that can be exploited equally by all local participants is open to debate (Owen-Smith and Powell, 2004). The canonical literature states that flows of knowledge within a district could be exploited directly by all district firms (Boari and Lipparini, 1999), whereas other studies posit that geographical location and the existence of shared capabilities alone do not guarantee firms' innovation (Hervás-Oliver et al., 2011). This study’s results show how it depends on the type of shared capabilities, which constitutes its third contribution. In the case of shared capabilities in exploitation the research findings corroborate that these capabilities could have a direct effect on incremental innovation. Nevertheless, to recognize and use the benefits of shared capabilities in exploration, firms first need to develop their internal exploration capabilities due to their more disruptive and complex foundations.

The findings also have some specific managerial implications. The study shows that managers who wish to capitalize on the complex and diverse nature of the knowledge flows comprising the shared capabilities in a tourist district must develop certain internal capabilities in order to improve innovation. However, depending on the firm's innovation strategy, intra-district firms should internally develop one type of specific knowledge capabilities and/or concentrate on managing and absorbing the shared capabilities in the destination. Firms located in a district that want to improve their products and processes by continuing their path in the market should concentrate on developing and participating in the district's support services, as well as external communication activities and strategic patterns that make up the district product. Or they should concentrate only on their own exploitation capabilities to distinguish themselves from the other intra-district firms, as both capabilities, internal and external, act in this case as substitutes. 
In contrast, firms that want to develop new products and processes should combine developing their internal capabilities in exploration with participating in learning processes in their immediate environment.

The findings should be interpreted with some caution. First, the analysis of radical and incremental innovation is limited to the domain of ITC technologies in tourism firms. Further research should examine innovation in other technological and organizational contexts. Second, the measures of capabilities and innovation rely on managers' judgments. Third, the study is cross-sectional, which limits the test of the causal inferences. Further research should explore the coevolution of the two types of capabilities and innovation through a longitudinal study.

\section{References}

Ahire, S.L., Golhar, D.Y. and Waller, M.A. (1996), "Development and validation of TQM implementation constructs”, Decision Sciences, Vol. 27 No. 1, pp. 23-56.

Aiken, L.S. and West, S.G. (1991), Multiple regression: testing and interpreting interactions, Sage, Newbury Park, C.A.

Amit, R. and Schoemaker, P.J. (1993), “Strategic assets and organizational rent", Strategic management journal, Vol. 14 No. 1, pp. 33-46.

Anderson, J.C. and Gerbing, D.W. (1988), "Structural equation modeling in practice: a review and recommended two-step approach", Psychological Bulletin, Vol. 103 No. 3, pp. 411-423.

Armstrong, J.S and Overton, T.S. (1977), "Estimating nonresponse bias in mail surveys", Journal of Marketing Research, Vol. 14, pp. 396-402.

Arnold, T.J., Fang, E. and Palmatier, R.W. (2011), "The effects of customer acquisition and retention orientations on a firm's radical and incremental innovation performance", Journal of the Academy of Marketing Science, Vol. 39, pp. 234-251.

Asheim, B.T. and Coenen, L. (2005), "Knowledge Bases and Regional Innovation Systems: Comparing Nordic Clusters”, Research Policy, Vol. 34 No. 8, pp. 1173-1190.

Atuahene-Gima, K. (2005), "Resolving the capability-rigidity paradox in new product performance", Journal of Marketing, Vol. 69, pp. 61-83.

Barney, J. (1991), "Firm resources and sustained competitive advantage", Journal of Management, Vol. 17, No.1, pp. 99-120.

Benner, M.J. and Tushman, M.L. (2003), "Exploitation, exploration, and process management: The productivity dilemma revisited", Academy of Management Review, Vol. 28, pp. 238-256.

Berchicci, L. (2013), “Towards an open R\&D system: internal R\&D investment, external knowledge acquisition and innovative performance", Research Policy, Vol. 42, pp. 117-127.

Boari, C. and Lipparini, A. (1999), "Networks within industrial districts. Organising knowledge creation and transfer by means of moderate hierarchies", Journal of Management and Governance, Vol. 3 No 4, pp. 339-360. 
Buhalis, D. and Law, R. (2008), "Progress in information technology and tourism management: 20 years on and 10 years after the Internet: The state of e-Tourism research", Tourism Management, Vol. 29, pp. 609-623.

Camisón, C. (2004), "Shared, competitive and comparative advantages: A competence-based view of industrial-district competitiveness", Environment and Planning A, Vol. 36, pp. 2227-2256.

Camisón, C. and Forés, B. (2010), "Knowledge absorptive capacity: new insights for its conceptualization and measurement", Journal of Business Research, Vol. 63 No. 7, 707-715.

Capello, R. (1999), "Spatial transfer of knowledge in high technology milieux: learning versus collective learning processes”, Regional Studies, Vol. 33 No. 4, pp. 353-365.

Capello, R. and Faggian, A. (2005), "Collective learning and relational capital in local innovation processes", Regional studies, Vol. 39 No. 1, pp. 75-87.

Chang, S.C., Tein, S.W. and Lee, H.-M. (2010), "Social capital, creativity, and new product advantage: an empirical study", International Journal of Electronic Business Management, Vol. 8 No. 1, pp. 43-55.

Chang, Y.Y., Hughes, M., Hotho, S. (2011). "Internal and external antecedents of SME's innovation ambidexterity outcomes", Management Decision, Vol. 49 No. 10, pp. 1658-1676.

Chuang, M. Y., Chen, C. J. and Lin, M. J. J. (2016), “The impact of social capital on competitive advantage: The mediating effects of collective learning and absorptive capacity", Management Decision, Vol. 54 No. 6, pp. 1443-1463.

Cotic-Svetina, A. and Jaklic, M. (2008), "Collective learning channels in clusters", Economic and Business Review for Central and South-Eastern Europe, Vol. 10 No. 4, pp. 289-306.

Cotic-Svetina, A., Jaklic, M. and Prodan, I. (2008), "Does collective learning in clusters contribute to innovation?", Science \& Public Policy, Vol. 35 No. 5, pp. 335-345.

Clausen, T.H., Korneliussen, T. and Madsen, E.L. (2013), "Modes of innovation, resources and their influence on product innovation: empirical evidence from R\&D active firms in Norway", Technovation, Vol. 33, pp. 225-233.

Cohen, J. and Cohen, P. (1983), Applied multiple regression/correlation analysis for the behavioral sciences, 2nd ed., Erlbaum, Hillsdale, NJ.

Cohen, P., Cohen, J., West, S.G. and Aiken, L S. (2003), Applied multiple regression/correlation analysis for the behavioral science, 3rd ed., Erlbaum, Hillsdale, NJ.

Cohen, W.M. and Levinthal, D.A. (1990), Absorptive capacity: a new perspective on learning and innovation", Administrative Science Quarterly, Vol. 35, pp. 128-152.

Cuevas-Rodriguez, G., Cabello-Medina, C. and Carmona-Lavado, A. (2013), "Internal and external social capital for radical product innovation: do they always work well together?", British Journal of Management, Vol. 25 No. 2, pp. 266-284.

Damanpour, F. (1991), “Organizational innovation: a meta-analysis of effects of determinants and moderators", Academy of Management Journal, Vol. 34, pp. 555-590.

Dess, G.G.D. and Beard, W. (1984), "Dimensions of Organizational Task Environments”, Administrative Science Quarterly, Vol. 29 No. 1, pp. 52-73. 
Dewar, R.D. and Dutton, J.E. (1986), “The adoption of radical and incremental innovations: An empirical analysis", Management Science, Vol. 32 No. 11, pp. 1422-1433.

Dillman, D.A. (1978), Mail and Telephone Surveys: The Total Design Method, John Wiley \& Sons, New York, NY.

Dyer, J. H. and Singh, H. (1998), "The relational view: Cooperative strategy and sources of interorganizational competitive advantage", Academy of management review, Vol. 23 No. 4, pp. 660-679.

Ettlie, J.E., Bridges, P. and O’Keefe, R.D. (1984), “Organization strategy and structural differences for radical versus incremental innovation”, Management Science, Vol. 30 No. 6, pp. 682-695.

Fløysand, A., and Jakobsen, S. (2002), "Clusters, social fields, and capabilities: Rules and restructuring in Norwegian fish-processing clusters", International Study of Management and Organisation, Vol. 31 No. 4, pp. 35-55

Fornell, C. and Larcker, F. (1981), "Evaluating structural equation models with unobservable varaibales and measurement errors", Journal of Marketing Research, Vol. 18 No.1, 39-50.

Foss, N.J. (1996), "Higher-order industrial capabilities and competitive advantage", Journal of Industry Studies, Vol. 3 No.1, pp. 1-20.

Giuliani, E. and Bell, M. (2005), “The micro-determinants of meso-level learning and innovation: Evidence from a Chilean wine cluster”, Research Policy, Vol. 34 No. 1, pp. 47-68.

Grant, R.M. (1991), “The resource-based theory of competitive advantage: implications for strategy formulation", California management review, Vol. 33 No. 3, pp. 114-135.

Grant, R.M. (1996), “Toward a knowledge based theory of the firm”, Strategic Management Journal, Vol. 17, pp. 109-122.

Guler, I. and Nerkar, A. (2012), "The impact of global and local cohesion on innovation in the pharmaceutical industry", Strategic Management Journal, Vol. 33, pp. 535- 549.

He, Z.L. and Wong, P.K. (2004), "Exploration vs. exploitation: An empirical test of the ambidexterity hypothesis", Organization science, Vol. 15 No. 4, pp. 481-494.

Henderson, R.M. and Clark, K.B. (1990), “Architectural innovation: The reconfiguration of existing product technologies and the failure of established firms", Administrative Science Quarterly, Vol. 35 No. 1, pp. 9-30.

Hervás-Oliver, J.L., Albors-Garrigós, J. and Gil-Pechuán, I. (2011), "Making sense of innovation by R\&D innovators in low technology contexts: a forgotten lessons for policymakers", Technovation, Vol. 31 No.9, pp. 427-446.

Hess, A.M. and Rothaermel, F.T. (2011), "When are assets complementary? Star scientists, strategic alliances, and innovation in the pharmaceutical industry", Strategic Management Journal, Vol. 32, pp. 895-909.

Inkpen, A. C. and Tsang, E.W.K. (2005), "Social capital, networks, and knowledge transfer", Academy of Management Review, Vol. 30 No. 1, pp. 146-165.

Kim, T.Y., Oh, H. and Swaminathan, A. (2006), "Framing interorganizational network change: A network inertia perspective", Academy of Management Review, Vol. 31 No.3, 704-720. 
Lavie, D., and Rosenkopf, L. (2006), "Balancing exploration and exploitation in alliance formation", Academy of Management Journal, Vol. 49, pp. 797-818.

Lawson, C. (1999), "Towards a competence theory of the region, Cambridge Journal of Economics", Vol. 23 No. 2, pp. 151-166.

Lawson, C. (2000), "Collective learning, system competences and epistemically significant moments", in Keeble, D. and Wilkinson, F. (Eds.), High-Technology Clusters, Networking and Collective Learning, eds., Ashgate, Aldershot, UK and Burlington, pp. 182-198.

Lawson, C. and Lorenz, E. (1999), "Collective learning, tacit knowledge and regional innovative capacity", Regional Studies, Vol. 33 No. 4, pp. 305-317.

Lazzaretti, M. and Petrillo, E. (2006), Tourism Local Systems and Networking, Elsevier Oxford.

Lei, H.S. and Huang, C.H. (2014), "Geographic clustering, network relationships and competitive advantage: Two industrial clusters in Taiwan”, Management Decision, Vol. 52 No. 5, pp. 852-871.

Levinthal, D.A. and March, J.G. (1993), "The myopia of learning", Strategic management journal, Vol. 14 No. S2, pp. 95-112.

Li, J. and Geng, S. (2012), "Industrial clusters, shared resources and firm performance", Entrepreneurship \& Regional Development, Vol. 24 No. 5-6, pp. 357-381.

Li, C.R., Lin, C.J., and Chu, C.P. (2008), "The nature of market orientation and the ambidexterity of innovations", Management Decision, Vol. 46 No. 7, pp. 1002-1026.

Li, H., de Zubielqui, G.C. and O'Connor, A. (2015), "Entrepreneurial networking capacity of cluster firms: a social network perspective on how shared resources enhance firm performance", Small business economics, Vol. 45 No. 3, pp. 523-541.

Malmberg, A. and Maskell, P. (2002), "The elusive concept of localization economies: Towards a knowledge-based theory of spatial clustering", Environment and Planning A, Vol. 34 No. 3, pp. 429-450.

Maskell, P. and Malberg, A. (1999), "Localised learning and industrial competitiveness", Cambridge Journal of Economics, Vol. 23 No. 2, pp. 167-185.

March, J.G., (1991), "Exploration and exploitation in organizational learning", Organization Science, Vol. 2 No. 1, pp. 71-87.

Martínez-Ros, E. and Orfila-Sintes, F. (2009), "Innovation activity in the hotel industry", Technovation, Vol. 29, pp. 632-641.

Menon, A., Bharadwaj, S.G. and Howell, R. (1996), "The quality and effectiveness of marketing strategy: effects of functional and dysfunctional conflict in intra- organizational relationships", Journal of the Academy of Marketing Science, Vol. 24, pp. 299-314.

Molteni, M. and Sainaghi, R. (1997), "Management di un distretto turistico", Economia \& Management, Vol. 6, pp. 93-104.

Nonaka, I. (1994), “A dynamic theory of organizational knowledge creation”, Organization Science, Vol. 5, pp. 14-37.

Novelli, M., Schmitz, B. and Spencer, T. (2006), "Networks, clusters and innovation in tourism: a UK experience", Tourism Management, Vol. 27 No. 6, pp. 1141-1152. 
Owen-Smith, J. and Powell, W.W. (2004), "Knowledge Networks in the Boston Biotechnology Community”, Organization Science, Vol. 15 No. 1, pp. 5-21.

Peteraf, M.A. (1993), “The cornerstones of competitive advantage: A resource-based view”, Strategic management journal, Vol. 14 No. 3, pp. 179-191.

Pinch, S., Henry, N., Jenkins, M. and Tallman, S. (2003), "From 'industrial districts' to 'knowledge clusters': A model of knowledge dissemination and competitive advantage in industrial agglomerations", Journal of Economic Geography, Vol. 3 No. 4, pp. 373-388.

Podsakoff, P M. and Organ, D.W. (1986), "Self-reports in organizational research: problems and prospects”, Journal of Management, Vol. 12 No. 4, pp. 531-544.

Quintana-García, C. and Benavides-Velasco, C.A. (2008), "Innovative competence, exploration and exploitation: The influence of technological diversification”, Research Policy, Vol. 37 No. 3, 492-507.

Sainaghi, R. (2006), "From contents to processes: versus a dynamic destination management model (DDMM)", Tourism Management, Vol. 27 No. 5, pp. 1053-1063.

Saxena, G.( 2005), "Relationships, networks and the learning regions: case evidence from the Peak District National Park”, Tourism Management, Vol. 26 No. 2, pp. 277-289.

Smallbone, D., North, D. and Leigh, R. (1993), "The use of external assistance by mature SMEs in the UK: Some policy implications”, Entrepreneurship and Regional Development, Vol. 5, pp. 279-295.

Sørensen, F. (2007), “The geographies of social networks and innovation in tourism”, Tourism Geographies, Vol. 9 No 1, pp. 22-48.

Storey, C. and Kahn, K. (2010), "The role of knowledge management strategies and task knowledge in stimulating service innovation”, Journal of Service Research, Vol. 13 No. 4, pp. 397-410.

Sundbo, J., Orfila-Sintes, F. and Sørensen F. (2007), "The innovative behaviour of tourism firmsComparative studies of Denmark and Spain”, Research Policy, Vol. 36 No. 1, pp. 88-106.

Teece, D.I., Pisano, G. and Shuen, A. (1997), "Dynamic capabilities and strategic management”, Strategic Management Journal, Vol. 18, pp. 509-533.

Tsai, W. and Ghoshal, S. (1998), "Social capital and value creation: The role of intrafirm networks", Academy of Management Journal, Vol. 41 No. 4, pp. 464-476.

Wang, C. L. and Rafiq, M. (2014), “Ambidextrous organizational culture, contextual ambidexterity and new product innovation: a comparative study of UK and Chinese High-Tech firms", British Journal of Management, Vol. 25, pp. 58-76.

Wernerfelt, B. (1984), “A resource-based view of the firm”, Strategic Management Journal, Vol. 5, pp. 171-180.

Wu, X., Geng, S., Li, J. adn Zhang, W. (2010), "Shared resources and competitive advantage in clustered firms: The missing link”, European Planning Studies, Vol. 18 No. 9, pp. 1391-1410.

Yang, T.T., Li, C.R. (2011), "Competence exploration and exploitation in new product development. The moderating effects of environmental dynamism and competitiveness", Management Decision, 49(9), 1444-1470. 


\section{TABLES AND FIGURES}

Table 1. Exploratory factor analysis of the construct measurements and composite reliability indexes.

\begin{tabular}{|c|c|c|c|c|c|c|c|}
\hline & Alpha & $\begin{array}{l}\text { Composite } \\
\text { reliability }\end{array}$ & & 1 & 2 & 3 & 4 \\
\hline \multirow{5}{*}{$\begin{array}{l}\text { 1.Exploration } \\
\text { capabilities }\end{array}$} & 0.887 & 0.850 & ER1 & 0.863 & 0.177 & 0.185 & 0.199 \\
\hline & & & ER2 & 0.829 & 0.158 & 0.102 & 0.231 \\
\hline & & & ER3 & 0.818 & 0.147 & 0.118 & 0.269 \\
\hline & & & ER4 & 0.558 & 0.088 & 0.246 & 0.177 \\
\hline & & & ER5 & 0.850 & 0.115 & 0.160 & 0.171 \\
\hline \multirow{5}{*}{$\begin{array}{l}\text { 2.Exploitation } \\
\text { capabilities }\end{array}$} & 0.910 & 0.763 & ET1 & 0.258 & 0.067 & 0.157 & 0.701 \\
\hline & & & ET2 & 0.071 & 0.120 & 0.047 & 0.604 \\
\hline & & & ET3 & 0.194 & 0.029 & 0.246 & 0.763 \\
\hline & & & ET4 & 0.224 & 0.079 & 0.054 & 0.696 \\
\hline & & & ET5 & 0.252 & 0.138 & 0.324 & 0.725 \\
\hline \multirow{5}{*}{$\begin{array}{l}\text { 3. Shared } \\
\text { capabilities in } \\
\text { exploration }\end{array}$} & 0.789 & 0.755 & SR1 & 0.162 & 0.750 & 0.196 & 0.095 \\
\hline & & & SR2 & 0.000 & 0.802 & 0.135 & 0.027 \\
\hline & & & SR3 & 0.169 & 0.648 & 0.015 & 0.183 \\
\hline & & & SR4 & 0.094 & 0.814 & 0.197 & 0.102 \\
\hline & & & SR5 & 0.129 & 0.593 & -0.012 & 0.020 \\
\hline \multirow{5}{*}{$\begin{array}{l}\text { 4. Shared } \\
\text { capabilities in } \\
\text { exploitation }\end{array}$} & 0.784 & 0.759 & ST1 & 0.224 & 0.061 & 0.743 & 0.168 \\
\hline & & & ST2 & 0.116 & 0.178 & 0.834 & 0.175 \\
\hline & & & ST3 & 0.128 & 0.136 & 0.877 & 0.096 \\
\hline & & & ST4 & 0.216 & -0.035 & 0.506 & 0.196 \\
\hline & & & ST5 & 0.039 & 0.320 & 0.471 & 0.069 \\
\hline
\end{tabular}

Extraction method: Principal Component Analysis.

Rotation method: Varimax with Kaiser Normalization. Rotation converged in 5 iterations. 
Table 2. Descriptive statistics and correlations of variables.

\begin{tabular}{|c|c|c|c|c|c|c|c|c|c|c|c|c|c|c|c|}
\hline Variable & Mean & $\begin{array}{l}\text { Standard } \\
\text { Deviation }\end{array}$ & 1 & 2 & 3 & 4 & 5 & 6 & 7 & 8 & 9 & 10 & 11 & 12 & 13 \\
\hline $1 \mathrm{Age}$ & 2.327 & 1.162 & & & & & & & & & & & & & \\
\hline 2 Size & 2.069 & 1.430 & $0.331^{* *}$ & & & & & & & & & & & & \\
\hline $\begin{array}{l}3 \text { Environmental } \\
\text { dynamism }\end{array}$ & 4.306 & 0.983 & -0.022 & 0.045 & & & & & & & & & & & \\
\hline 4 Act. Accommodation & 0.300 & 0.459 & $0.202^{* *}$ & $0.353^{* *}$ & -0.011 & & & & & & & & & & \\
\hline $\begin{array}{l}5 \text { Act. Restaurant, } \\
\text { catering }\end{array}$ & 0.379 & 0.485 & $-0.140^{* *}$ & $-0.210^{* *}$ & -0.002 & $-0.512 * *$ & & & & & & & & & \\
\hline $\begin{array}{l}6 \text { Act. Travel agencies } \\
\text { and tour operators }\end{array}$ & 0.110 & 0.313 & -0.023 & -0.001 & 0.049 & $-0.230 * *$ & $-0.274 * *$ & & & & & & & & \\
\hline 7 Act. Transport & 0.039 & 0.194 & 0.057 & 0.029 & 0.013 & $-0.132 * *$ & $-0.158 * *$ & $-0.071^{*}$ & & & & & & & \\
\hline $\begin{array}{l}8 \text { Act. Complementary } \\
\text { activities }\end{array}$ & 0.172 & 0.377 & $-0.069^{*}$ & $-0.172 * *$ & -0.031 & $-0.298 * *$ & $-0.356 * *$ & $-0.160 * *$ & $-0.092 * *$ & & & & & & \\
\hline $\begin{array}{l}9 \text { Exploration } \\
\text { capabilities }\end{array}$ & 3.451 & 1.358 & 0.013 & $0.330^{* *}$ & $0.211^{* *}$ & $0.135^{* *}$ & $-0.211 * *$ & $0.188^{* *}$ & 0.007 & -0.053 & & & & & \\
\hline $\begin{array}{l}10 \text { Exploitation } \\
\text { capabilities }\end{array}$ & 3.961 & 1.557 & 0.066 & $0.208^{*}$ & $0.159^{* *}$ & 0.048 & $-0.116^{* *}$ & $0.126^{* *}$ & $0.082 *$ & -0.057 & $0.549^{* *}$ & & & & \\
\hline $\begin{array}{l}11 \text { Shared exploration } \\
\text { capabilities }\end{array}$ & 3.986 & 0.918 & 0.072 & $0.214^{* *}$ & 0.003 & 0.042 & $-0.095 * *$ & $0.079^{*}$ & $0.077 *$ & -0.031 & $0.299^{* *}$ & $0.140^{* * *}$ & & & \\
\hline $\begin{array}{l}12 \text { Shared exploitation } \\
\text { capabilities }\end{array}$ & 4.197 & 1.280 & $0.103^{* *}$ & $0.335^{* *}$ & $0.121^{* *}$ & $0.204^{* *}$ & $-0.250 * *$ & $0.103^{* *}$ & 0.036 & -0.033 & $0.415^{* *}$ & $0.316^{\text {*** }}$ & $0.360^{\text {** }}$ & & \\
\hline 13 Radical innovation & 1.236 & 2.042 & $0.090^{*}$ & $0.463^{* *}$ & $0.120^{* *}$ & $0.257^{* *}$ & $-0.304 * *$ & $0.230^{* *}$ & 0.014 & $-0.117 * *$ & $0.474^{* *}$ & $0.353^{* *}$ & $0.229^{* *}$ & $0.357^{* *}$ & \\
\hline $\begin{array}{l}14 \text { Incremental } \\
\text { innovation }\end{array}$ & 4.107 & 3.212 & $0.198^{* *}$ & $0.527^{* *}$ & $0.171^{* *}$ & $0.357^{* *}$ & $-0.453 * *$ & $0.264^{* *}$ & $0.080^{*}$ & $-0.110 * *$ & $0.445^{* *}$ & $0.304 * *$ & $0.209^{* *}$ & $0.388^{* *}$ & $0.590^{* *}$ \\
\hline
\end{tabular}


Table 3. Standardized regression estimates (t-values).

\begin{tabular}{|c|c|c|c|c|c|c|}
\hline & \multicolumn{3}{|c|}{ RADICAL INNOVATION } & \multicolumn{3}{|c|}{ INCREMENTAL INNOVATION } \\
\hline & Model 1 & Model 2 & Model 3 & Model 4 & Model 5 & Model 6 \\
\hline \multicolumn{7}{|l|}{ Control variables } \\
\hline Age & $\begin{array}{l}-0.098 * \\
(-2.461)\end{array}$ & $\begin{array}{l}-0.059 \\
(-1.567)\end{array}$ & $\begin{array}{l}-0.064 \\
(-1.701)\end{array}$ & $\begin{array}{l}0.018 \\
(0.745)\end{array}$ & $\begin{array}{l}0.032 \\
(1.389)\end{array}$ & $\begin{array}{l}0.032 \\
(1.390)\end{array}$ \\
\hline Size & $\begin{array}{l}0.360 * * * \\
(8.418)\end{array}$ & $\begin{array}{l}0.279 * * * \\
(6.647)\end{array}$ & $\begin{array}{l}0.256^{* * *} \\
(6.123)\end{array}$ & $\begin{array}{l}0.402 * * * \\
(15.688)\end{array}$ & $\begin{array}{l}0.336 * * * \\
(13.075)\end{array}$ & $\begin{array}{l}0.331 * * * \\
(12.701)\end{array}$ \\
\hline Environmental dynamism & $\begin{array}{l}0.089 * \\
(2.511)\end{array}$ & $\begin{array}{l}0.032 \\
(0.915)\end{array}$ & $\begin{array}{l}0.051 \\
(1.124)\end{array}$ & $\begin{array}{l}0.120 * * * \\
(5.160)\end{array}$ & $\begin{array}{l}0.089 * * * \\
(3.921)\end{array}$ & $\begin{array}{l}0.090 * * * \\
(3.911)\end{array}$ \\
\hline Act. Accommodation & $\begin{array}{l}0.100 \\
(1.820)\end{array}$ & $\begin{array}{l}0.137 * * \\
(2.639)\end{array}$ & $\begin{array}{l}0.122 * \\
(2.335)\end{array}$ & $\begin{array}{l}0.184 * * * \\
(5.417)\end{array}$ & $\begin{array}{l}0.177 * * * \\
(5.406)\end{array}$ & $\begin{array}{l}0.170^{* * *} \\
(5.188)\end{array}$ \\
\hline Act. Restaurant, catering & $\begin{array}{l}-0.170 * * \\
(-3.265)\end{array}$ & $\begin{array}{l}-0.104^{*} \\
(-2.091)\end{array}$ & $\begin{array}{l}-0.095 \\
(-1.895)\end{array}$ & $\begin{array}{l}-0.188^{* * *}(- \\
5.717)\end{array}$ & $\begin{array}{l}-0.176^{* * *}(- \\
5.555)\end{array}$ & $\begin{array}{l}-0.179 * * * \\
(-5.626)\end{array}$ \\
\hline $\begin{array}{l}\text { Act. Travel agencies and } \\
\text { tour operators }\end{array}$ & $\begin{array}{l}0.247 * * * \\
(5.830)\end{array}$ & $\begin{array}{l}0.223 * * * \\
(5.575)\end{array}$ & $\begin{array}{l}0.209 * * * \\
(5.220)\end{array}$ & $\begin{array}{l}0.254 * * * \\
(8.971)\end{array}$ & $\begin{array}{l}0.224 * * * \\
(8.169)\end{array}$ & $\begin{array}{l}0.217 * * * \\
(7.944)\end{array}$ \\
\hline Act. Transport & $\begin{array}{l}-0.023 \\
(-0.577)\end{array}$ & $\begin{array}{l}-0.004 \\
(-0.101)\end{array}$ & $\begin{array}{l}-0.002(- \\
0.054)\end{array}$ & $\begin{array}{l}0.079^{* *} \\
(3.100)\end{array}$ & $\begin{array}{l}0.069 * * \\
(2.797)\end{array}$ & $\begin{array}{l}0.065 * * \\
(2.657)\end{array}$ \\
\hline \multicolumn{7}{|l|}{ Main variables } \\
\hline Exploration capabilities & & $\begin{array}{l}0.237 * * * \\
(5.338)\end{array}$ & $\begin{array}{l}0.216 * * * \\
(4.670)\end{array}$ & & $\begin{array}{l}0.149 * * * \\
(5.343)\end{array}$ & $\begin{array}{l}0.132 * * * \\
(4.549)\end{array}$ \\
\hline $\begin{array}{l}\text { Exploration capabilities } \\
\text { squared }\end{array}$ & & $\begin{array}{l}0.080^{*} \\
(1.868)\end{array}$ & $\begin{array}{l}0.040 \\
(0.974)\end{array}$ & & $\begin{array}{l}-0.096 * * *(- \\
4.080)\end{array}$ & $\begin{array}{l}-0.085 * * \\
(-3.371)\end{array}$ \\
\hline Exploitation capabilities & & $\begin{array}{l}0.051 \\
(1.196)\end{array}$ & $\begin{array}{l}0.035 \\
(0.814)\end{array}$ & & $\begin{array}{l}0.134 * * * \\
(4.409)\end{array}$ & $\begin{array}{l}0.146 * * * \\
(4.532)\end{array}$ \\
\hline $\begin{array}{l}\text { Exploitation capabilities } \\
\text { squared }\end{array}$ & & $\begin{array}{l}0.067 \\
(1.763)\end{array}$ & $\begin{array}{l}0.038 \\
(0.985)\end{array}$ & & $\begin{array}{l}0.127 * * * \\
(4.636)\end{array}$ & $\begin{array}{l}0.138 * * * \\
(4.801)\end{array}$ \\
\hline \multicolumn{7}{|l|}{ Interaction effects } \\
\hline $\begin{array}{l}\text { Shared exploration } \\
\text { capabilities }\end{array}$ & & & $\begin{array}{l}0.010 \\
(0.226)\end{array}$ & & & $\begin{array}{l}-0.013 \\
(-0.437)\end{array}$ \\
\hline $\begin{array}{l}\text { Shared exploitation } \\
\text { capabilities }\end{array}$ & & & $\begin{array}{l}0.035 \\
(0.694)\end{array}$ & & & $\begin{array}{l}0.095 * * \\
(2.951)\end{array}$ \\
\hline $\begin{array}{l}\text { Exploration capabilities } \mathrm{x} \\
\text { shared exploration } \\
\text { capabilities }\end{array}$ & & & $\begin{array}{l}0.111^{*} \\
(2.548)\end{array}$ & & & $\begin{array}{l}0.004 \\
(0.133)\end{array}$ \\
\hline $\begin{array}{l}\text { Exploration capabilities } \\
\text { squared } x \text { shared exploration } \\
\text { capabilities }\end{array}$ & & & $\begin{array}{l}0.025 \\
(0.512)\end{array}$ & & & $\begin{array}{l}0.035 \\
(1.018)\end{array}$ \\
\hline $\begin{array}{l}\text { Exploitation capabilities } \mathrm{x} \\
\text { shared exploitation } \\
\text { capabilities }\end{array}$ & & & $\begin{array}{l}0.052 \\
(1.260)\end{array}$ & & & $\begin{array}{l}-0.068 * * \\
(-2.758)\end{array}$ \\
\hline $\begin{array}{l}\text { Exploitation capabilities } \\
\text { squared } \mathrm{x} \text { shared } \\
\text { exploitation capabilities }\end{array}$ & & & $\begin{array}{l}0.061 \\
(1.218)\end{array}$ & & & $\begin{array}{l}-0.063^{*} \\
(-2.005)\end{array}$ \\
\hline
\end{tabular}




\begin{tabular}{lllllll} 
Adjusted $\mathrm{R}^{2}$ & 0.281 & 0.365 & 0.383 & 0.448 & 0.494 & 0.499 \\
$\mathrm{R}^{2}$ change & & 0.087 & 0.024 & & 0.048 & 0.008 \\
Degrees of Freedom & $7 / 527$ & $4 / 523$ & $6 / 517$ & $7 / 1011$ & $4 / 1007$ & $6 / 1001$ \\
F value & $30.854^{* * *}$ & $28.898^{* * *}$ & $20.458^{* * *}$ & $119.074 * * *$ & $91.390^{* * *}$ & $60.581^{* * *}$ \\
F change & & $18.360^{* * *}$ & $3.478^{* *}$ & & $23.990^{* * *}$ & $2.550^{*}$ \\
\hline
\end{tabular}

*** $p<0.001 ;{ }^{* *} p<0.01 ;{ }^{*} p<0.05$ 


\section{FIGURES}

Figure 1. Exploration capabilities effect on radical innovation.

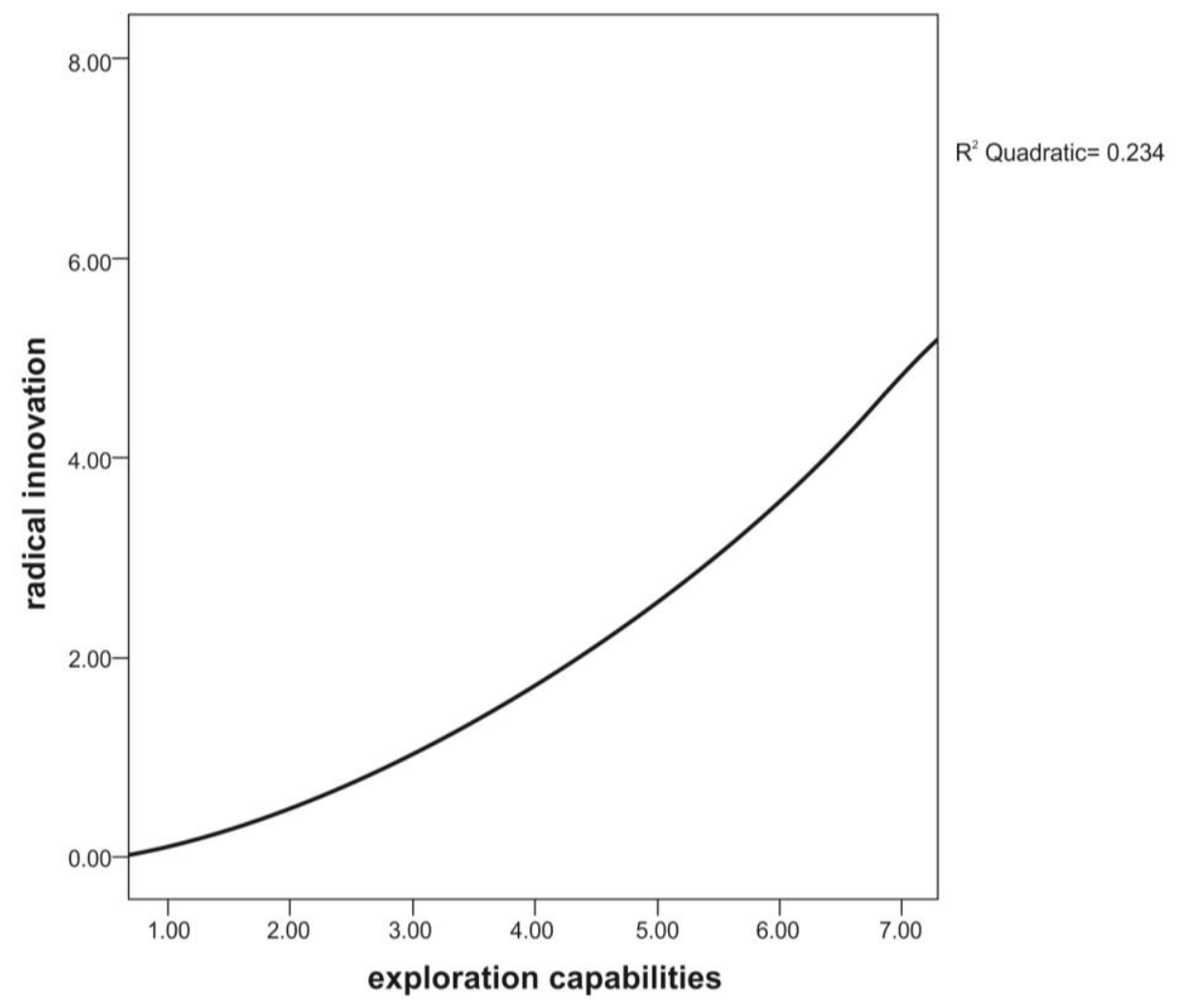

Figure 2. Moderating effect of shared capabilities in exploration.

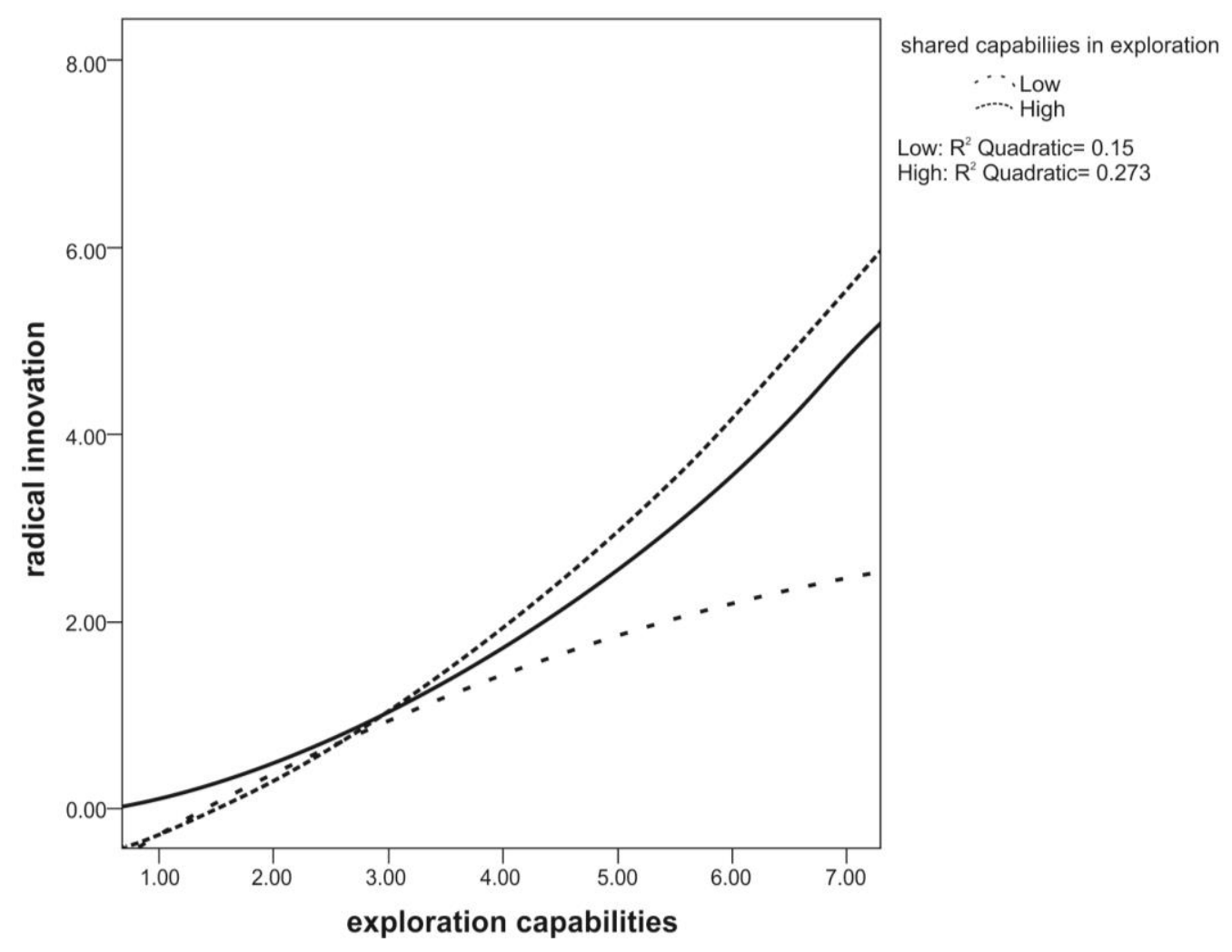


Figure 3. Exploration capabilities effect on incremental innovation.

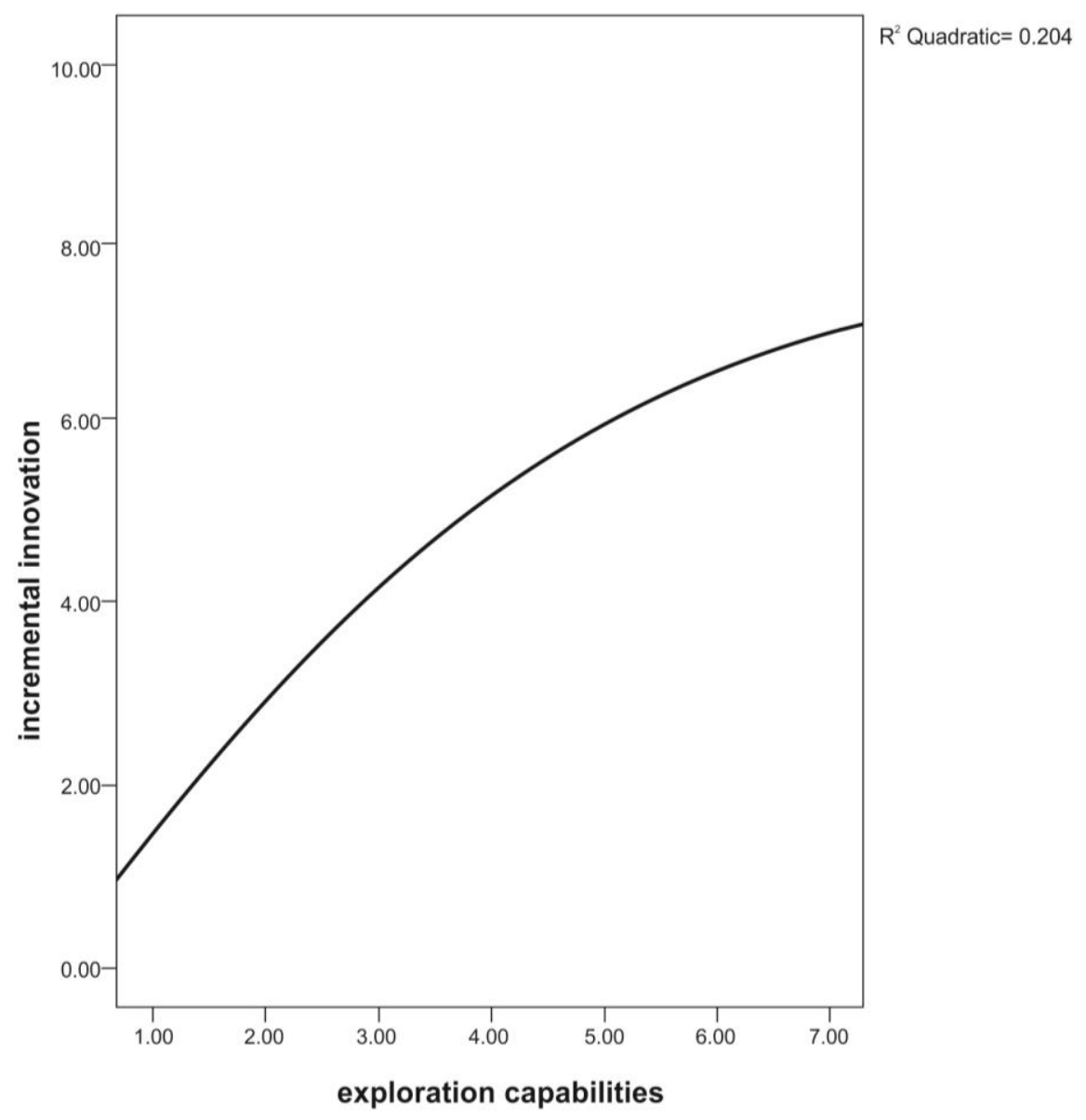

Figure 4. Exploitation capabilities effect on incremental innovation.

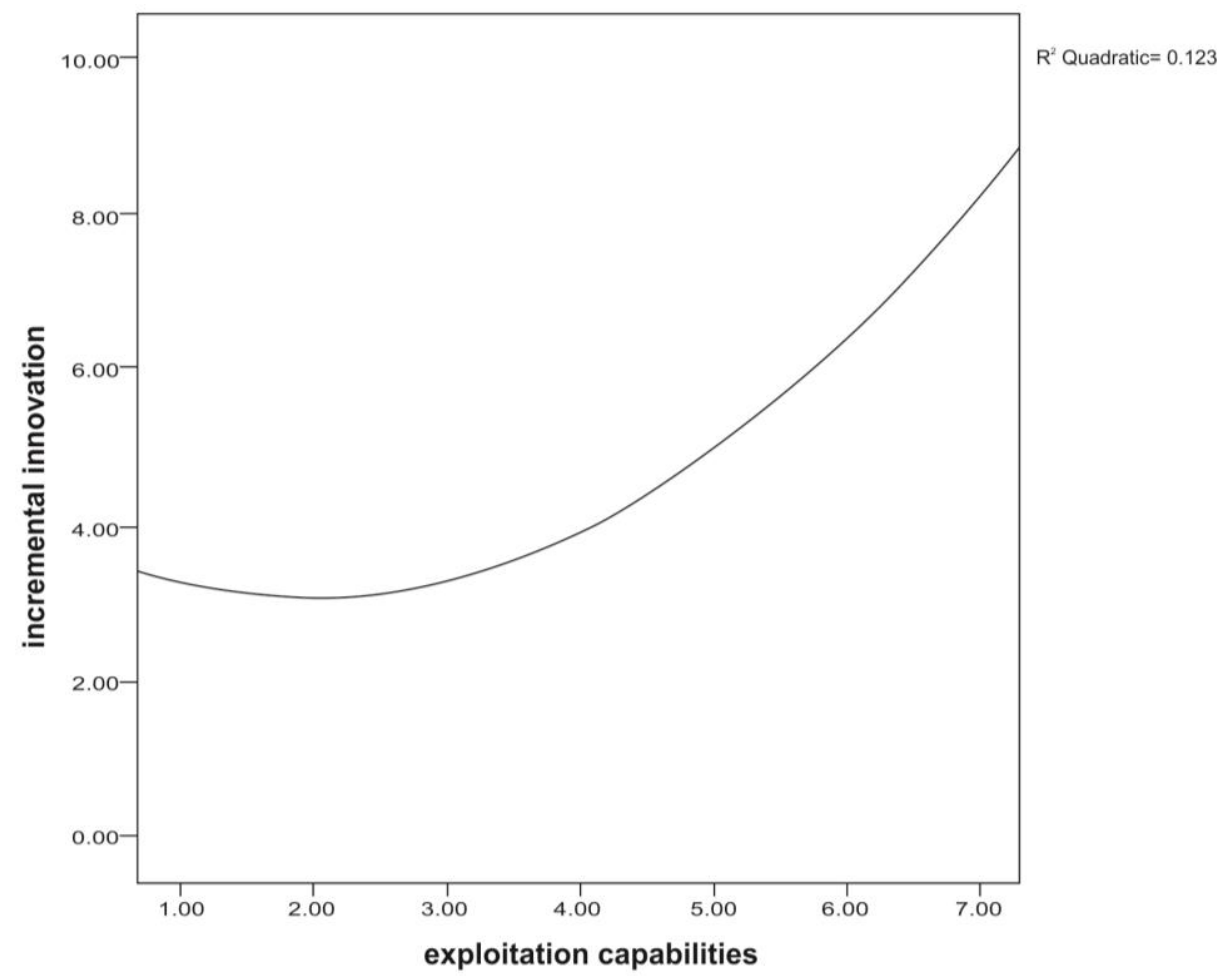


Figure 5. Moderating effect of shared capabilities on exploitation.

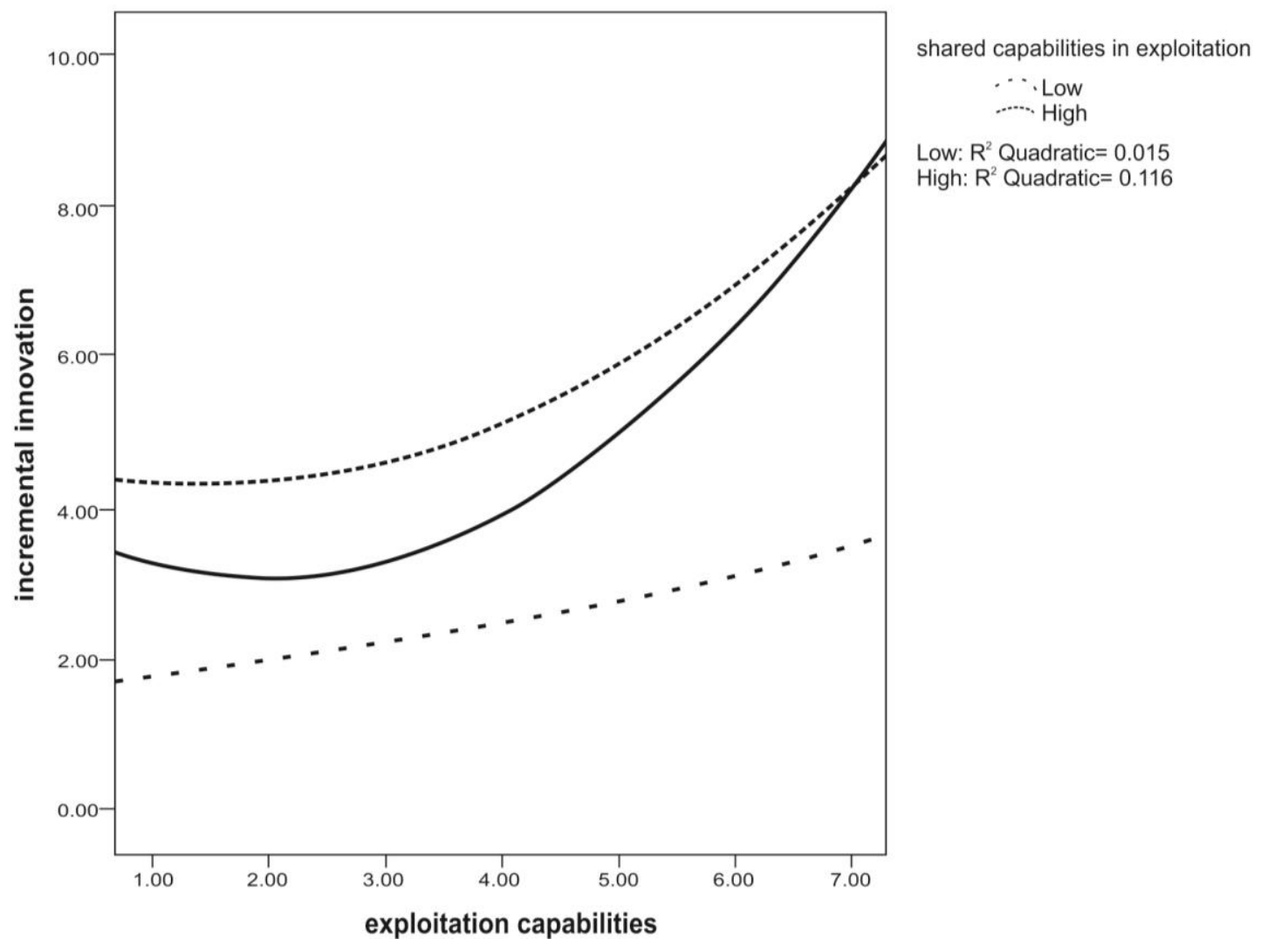


Appendix

Construct

Measure

Radical innovation Indicate whether your company has introduced the following technologies in its establishments.

RI1 Workflow management tools. Integration in computer reservation systems (CRS) or global distribution systems (GDS)

RI2 Relational databases (CRM) to improve customer service.

RI3 Integrated management software (ERP).

RI4 Systems for knowledge management (search engines, knowledge maps, etc.).

RI5 Development of sustainable buildings.

RI6 Document management tools.

RI7 Electronic cards for customer follow-up.

RI8 Energy saving technologies.

Incremental innovation

Exploration capabilities

Exploitation capabilities
Indicate whether your company has introduced the following technologies in its establishments.

II1 Computers for managers.

II2 Computerized customer management.

II3 Computerized management of purchasing and suppliers.

II4 Computerized accounting.

II5 Broadband Internet connection.

II6 Own Internet domain.

II7 Company website hosted on external server.

II8 Company website hosted on own server.

II9 E-mail for staff.

Over the last three years, to what extent has your firm

ER1 Acquired manufacturing technologies and skills entirely new to the firm?

ER2 Learned product development skills and processes (such as product design, prototyping new products, timing of new product introductions, and customizing products for local markets) entirely new to the industry?

ER3 Acquired entirely new managerial and organizational skills that are important for innovation (such as forecasting technological and customer trends; identifying emerging markets and technologies; coordinating and integrating R\&D; marketing, manufacturing, and other functions; managing the product development process)?

ER4 Learned new skills in areas such as funding new technology, staffing R\&D function, training and development of $R \& D$, and engineering personnel for the first time?

ER5 Strengthened innovation skills in areas where it had no prior experience?

Over the last three years, to what extent has your firm

ET1 Upgraded current knowledge and skills for familiar products and technologies?

ET2 Invested in enhancing skills in exploiting mature technologies that improve productivity of current innovation operations?

ET3 Enhanced competencies in searching for solutions to customer problems that are near to existing solutions rather than completely new solutions?

ET4 Upgraded skills in product development processes in which the firm already possesses significant experience?

ET5 Strengthened its knowledge and skills for projects that improve efficiency of existing innovation activities? 
Shared capabilities in exploration

Shared capabilities in exploitation
Evaluate, according to your perception and the available information, the situation in the tourist destination or municipality in which your business is located (if located in multiple sites, consider the average of all of them) for the areas identified below in relation to the average of the competitor destinations or municipalities, on a scale of 1 to 7 where 1 is "much worse than our competitors", 4 is "on a par with our competitors", and 7 is "much better than our competitors".

SR1 Support services are available to establish cooperation agreements with firms within the tourist destination/district that are difficult to reproduce outside it.

SR2 Firms benefit from common learning processes (on products, processes, technologies, markets and customers) stimulated by leading R\&D centers in the industry such as technological institutes or universities, suppliers or clients located in the tourist destination/district.

SR3 Knowledge is created through cooperation with customers, suppliers, competitors, and/or R\&D organizations (frequency and importance of relationships and cooperation to create knowledge and innovations by developing joint projects, strategic alliances, business meetings, temporary exchanges of staff, etc).

SR4 There is a model or pattern of relationships for the informal transmission of innovations, technologies and knowledge within the tourist destination/district that cannot be reproduced outside the area.

SR5 Availability of qualified specialized human capital.

Evaluate, according to your perception and the available information, the situation in the tourist destination or municipality in which your business is located (if located in multiple sites, consider the average of all of them) for the areas identified below in relation to the average of the competitor destinations or municipalities, on a scale of 1 to 7 where 1 is "much worse than our competitors", 4 is "on a par with our competitors", and 7 is "much better than our competitors".

ST1 Firms benefit from the external communication activities carried out cooperatively by distributors, groups of competitors, or business associations in the area.

ST2 There is an overall strategic plan and policies that are important to improving the tourist destination/district as a whole.

ST3 A comprehensive tourist product is offered through the cooperation of the destination agents.

ST4 Establishments are sited in a priviledged environment.

ST5 Cost savings achieved by sharing resources, tasks or staff among various activities.

Environmental dynamism
Evaluate the degree of intensity with which the following charateristics are present in your firm on a scale of 1 to 7 , where 1 is very low and 7, very high.

ED1 Unpredictibility of challenges resulting from environmental changes.

ED2 Frequency of change in relevant areas of the environment.

ED3 Demand instability (difficult to predict).

ED4 The cost that adapting to change represents for the firm.

ED5 The time the firm needs to respond to changes. 